Article

\title{
Daurichromenic Acid from the Chinese Traditional Medicinal Plant Rhododendron dauricum Inhibits Sphingomyelin Synthase and A $\beta$ Aggregation
}

\author{
Hadya Virupaksha Deepak ${ }^{1}$, Mahadeva M. M. Swamy ${ }^{1}$, Yuta Murai ${ }^{1,2}$ D, Yoshiko Suga ${ }^{2}$, \\ Masaki Anetai ${ }^{2}$, Takuro Yo ${ }^{3}$, Masahiro Kuragano ${ }^{3}{ }^{(D}$, Koji Uwai $^{3}$, Kiyotaka Tokuraku ${ }^{3}{ }^{(D)}$ \\ and Kenji Monde 1,2,*(D) \\ 1 Graduate School of Life Science, Hokkaido University, Sapporo 001-0021, Japan; \\ deepudarshu@sci.hokudai.ac.jp (H.V.D.); mswamy.madegowda@gmail.com (M.M.M.S.); \\ ymurai@sci.hokudai.ac.jp (Y.M.) \\ 2 Faculty of Advanced Life Science, Hokkaido University, Sapporo 001-0021, Japan; \\ suga@sci.hokudai.ac.jp (Y.S.); glycinoeclepin-a@hb.tp1.jp (M.A.) \\ 3 Department of Applied Sciences, Muroran Institute of Technology, 27-1 Mizumoto-cho, \\ Muroran 050-8585, Japan; udasan_16@yahoo.co.jp (T.Y.); gano@mmm.muroran-it.ac.jp (M.K.); \\ uwai@mmm.muroran-it.ac.jp (K.U.); tokuraku@mmm.muroran-it.ac.jp (K.T.) \\ * Correspondence: kmonde@sci.hokudai.ac.jp
}

Academic Editor: Pierluigi Plastina

Received: 10 August 2020; Accepted: 2 September 2020; Published: 7 September 2020

\begin{abstract}
Species of the genus Rhododendron have been used in traditional Chinese medicine, with the medicinal herb "Manshanfong" used as an expectorant and for the treatment of acute bronchitis. Daurichromenic acid (DCA), a constituent of Rhododendron dauricum, is a meroterpenoid with antibacterial, anti-HIV, and anti-inflammatory activities. However, the mechanisms underlying these pharmacologic activities are poorly understood. To develop new drugs based on DCA, more information is required regarding its interactions with biomolecules. The present study showed that DCA inhibits the activity of the enzyme sphingomyelin synthase, with an $\mathrm{IC}_{50}$ of $4 \mu \mathrm{M}$. The structure-activity relationships between DCA and sphingomyelin synthase were evaluated using derivatives and cyclized hongoquercin A. In addition, DCA was found to inhibit amyloid $\beta$ aggregation. These results may help in the design of effective drugs based on DCA.
\end{abstract}

Keywords: daurichromenic acid; sphingomyelin synthase; amyloid $\beta$; dual inhibitor; lipid-related disease

\section{Introduction}

Traditional medicinal plants are promising sources of naturally occurring drugs, especially of natural products targeting membrane proteins, including membrane receptors and enzymes. Daurichromenic acid (DCA), a meroterpenoid consisting of orsellinic acid and sesquiterpene moieties, was isolated from the leaves of Rhododendron dauricum, a plant growing in the wild in northern China, eastern Siberia, and the Japanese island of Hokkaido [1]. This species of Rhododendron has been used in traditional Chinese medicine, with the medicinal herb "Manshanfong" used as an expectorant and to treat various diseases, such as acute and chronic bronchitis [2]. DCA has also been reported to have antibacterial activity against Gram-positive bacteria [3], as well as having anti-HIV [4], and anti-inflammatory [5] activity, suggesting that DCA may be a medicinal resource in the development of derivatives that can act as novel drugs to treat these conditions. Although DCA exhibits various pharmacological activities, including the induction of cell death in cultured cells [6], its molecular mechanisms of activity remain unclear. Thus, a deeper understanding of its mechanisms 
of activity in human (patho)physiology and its potential therapeutic uses is required for new drug discovery and pharmacotherapeutics.

Sphingomyelin synthase (SMS) is a cell membrane-located lipid-metabolizing enzyme, which has been reported to play crucial roles in cell death, proliferation, and migration [7]. SMS knockout mice showed a decrease in plasma concentrations of inflammatory cytokines [8], as well as resistance to the development of high-fat diet-induced obesity [9], insulin resistance [10], Alzheimer's disease [11], and tumorigenesis [12]. SMS activity was shown to be inhibited by the naturally occurring compounds ginkgolic acid, from the leaves of Gingko biloba [13], and malabaricones A-C and E, from the fruits of M. cinnamomea [14]. The latter inhibitors may be especially safe, with fewer side effects than other SMS inhibitors, because they were isolated from an edible fruit. Similarly, DCA may directly or indirectly affect SMS activity, regulating cell death and anti-inflammatory activity. Elucidation of the mechanism by which DCA interacts with SMS could contribute to the development of novel therapeutic agents. Moreover, the nontoxic nature of DCA makes it a suitable candidate for further development as a new drug or medicinal supplement.

Modulation of the activity of a specific enzyme or receptor by a small molecule is one of the cornerstones of modern target-based drug discovery. However, small molecules frequently bind to multiple target molecules, influencing both drug efficacy and safety $[15,16]$. Although the one-drug-hits-one target approach was dominant in the post-genomic era, it is regarded as inadequate to address complex diseases [17]. The multitarget approach has become a fruitful area of drug discovery, particularly in developing medicines to treat major complex diseases. For example, natural products such as genistein [18], curcumin, and tashinone [19] have been reported to inhibit amyloid $\beta$ (A $\beta)$ and human islet amylin (hIAPP) associated with type 2 diabetes. Another compound, miltirone, isolated from Salvia miltiorrhiza, was shown to be a dual inhibitor of P-glycoprotein and cell growth in doxorubicin-resistant HepG2 cells [20]. Furthermore, cannabinoid compounds, which are structurally related to DCA, have been reported to inhibit the formation of $A \beta$ fibrils and aggregates, which have neuronal and microglial-activated neurotoxicity [21].

To determine the biological properties of DCA and its derivatives and whether they are promising candidate drugs, the ability of these compounds to inhibit SMS activity was analyzed, as was the structure-activity relationship of these compounds in cell-based SMS assays. Furthermore, the effects of DCAs and natural SMS inhibitors on A $\beta$ aggregation were assessed by microtiter-scale high-throughput screening (MSHTS) assays.

\section{Results and Discussion}

\subsection{Preparation of Daurichromenic Acid (1) and Its Derivatives (2-7)}

The identity of DCA (1) isolated from Rhododendron dauricum was confirmed by ${ }^{1} \mathrm{H}$ - and ${ }^{13} \mathrm{C}$-nuclear magnetic resonance (NMR) and by electrospray ionization-mass spectrometry (ESI-MS) and compared with previously reported values [22]. To understand the structure-activity relationship (SAR) between DCA and its target molecules, DCA derivatives were synthesized. Compound (2) was prepared from DCA by selective methyl esterification of its carboxylic acid moiety by TMS- $\mathrm{CH}_{2} \mathrm{~N}_{2}$. Compound (3) was prepared by protecting the carboxylic acid and hydroxy groups with iodomethane, and compound (4) was prepared by hydrolysis of the methyl ester group of compound (3). Subsequently, hongoquercin A (7), which has been isolated from an unidentified terrestrial fungus [23] and exhibits antibacterial properties toward methicillin-resistant Staphylococcus aureus and vancomycin-resistant Enterococcus faecium [24,25], was prepared from compound (2). In the first step, compound (2) was treated with $\mathrm{FeCl}_{3}$ to obtain the cyclized derivative compound 5 (5). The methyl ester group of (5) was hydrolyzed to yield compound (6), and the double bond at the benzyl position of compound (6) was reduced by $\mathrm{Pd} / \mathrm{C}$ and $\mathrm{H}_{2}$ to obtain hongoquercin A (7) in moderate yield (Scheme 1). 
<smiles>CC(C)=CCC/C(C)=C/CC[C@]1(C)C=Cc2c(cc(C)c(C(=O)O)c2O)O1</smiles>

DCA (1)<smiles>CCCCCC(C)OC(=O)OCC</smiles><smiles>COC(=O)c1c(C)cc2c(c1O)C=C[C@](C)(CC/C=C(\C)CCC=C(C)C)O2</smiles>

(2)

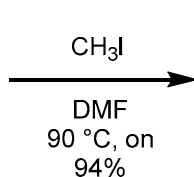

$94 \%$<smiles>COC(=O)c1c(C)cc2c(c1OC)C=C[C@@](C)(CC/C=C(\C)CCC=C(C)C)O2</smiles>

(3)<smiles>COc1c2c(cc(C)c1C(=O)O)O[C@@](C)(CC/C=C(\C)CCC=C(C)C)C=C2</smiles>

(4)

$$
\mathrm{FeCl}_{3} \downarrow \begin{gathered}
\text { toluene, } \mathrm{rt} \\
46 \%
\end{gathered}
$$<smiles>COC(=O)c1c(C)cc2c(c1O)C=C1C(C)(CCC3[C@H](C)CCC[C@@]13C)O2</smiles>

(5)

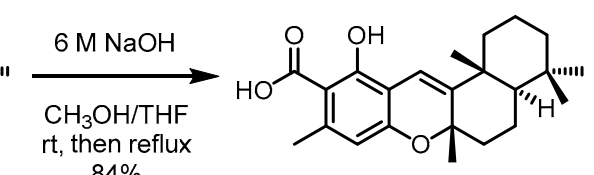

(6)

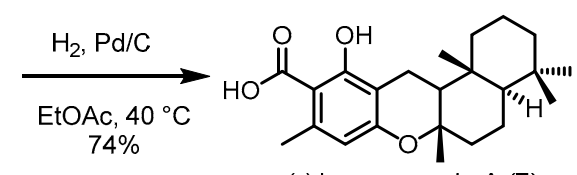

(-) hongoquercin $\mathrm{A}(7)$

Scheme 1. Preparation and synthesis of DCA (1) and its derivatives.

\subsection{SMS Inhibition by DCA and Its Derivatives}

The ability of DCA and its derivatives to inhibit the SMS isozymes SMS1 and SMS2 was evaluated using a cell lysate assay and the fluorescent substrate C6-NBD (4-nitrobenzo-2-oxa-1,3-diazole)-Cer. DCA (1) and compounds 4,6 , and $\mathbf{7}$ showed relatively moderate inhibitory activities, with $\mathrm{IC}_{50}$ values of 7, 17, 9, and $4 \mu \mathrm{M}$, respectively, for SMS1, and 4, 10, 7, and $5 \mu \mathrm{M}$, respectively, for SMS2 (Figure 1), similar to other natural compounds $[13,14]$. These findings indicated that the methyl esters of DCA derivatives, compounds $\mathbf{2}, \mathbf{3}$, and $\mathbf{5}$, were inactive in these assays. Thus, the carboxylic acid group of DCAs are essential moieties for their inhibition of SMSs. However, the SMS has not been succeeded in its crystallization. Therefore, a direct comparison with the previously isolated SMS inhibitor ginkgolic acid [13] has been examined. The chemical similarity of ginkogolic acid to DCA, as it is a long alkyl chain and a carboxylic acid moiety in an aromatic ring, shows that these two inhibitors also have the same functional group participation to inhibit SMS. Further, a previous report [26] concerning the mode of action for $A \beta$ aggregation inhibition for small molecules gave the insight that the crucial role of a hydrophobic-side hydrocarbon chain and an aromatic ring as well as its two hydrophilic functions causes significant interaction with the amyloid. 

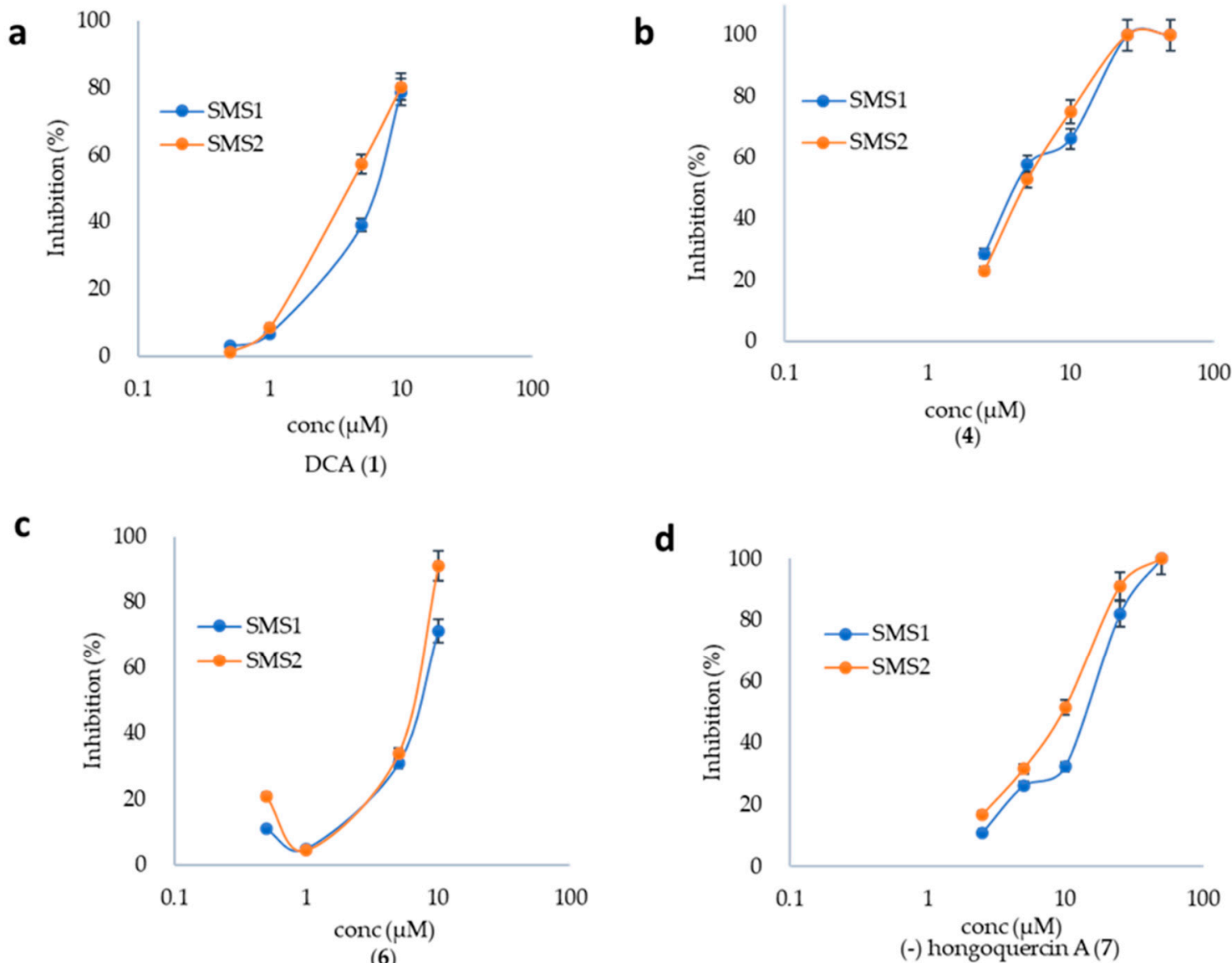

Figure 1. Inhibition of SMS1 and SMS2 activities by (a) DCA (1), (b) derivative (4), (c) derivative (6) and (d) derivative (7). IC 50 values were measured using a cell lysate assay. SMS-expressing cell lysates and compounds were incubated for $3 \mathrm{~h}$ at $37^{\circ} \mathrm{C}$, and the extracted fluorescent lipids were directly analyzed by HPLC. Each point represents the mean \pm SD of triplicate assays.

\subsection{Inhibition of A Aggregation by DCA and Its Derivatives}

Alzheimer's disease (AD) is a multifactorial disease, which is believed to be caused by complex interactions among several contributing patho-mechanisms. The ability of DCA and its derivatives, along with other natural compounds, ginkgolic acids $(\mathbf{8}, \mathbf{9})$ (Figure 2) and malabaicone A-C (10, 11 and 12), to inhibit $A \beta_{42}$ aggregation was evaluated by microtiter-scale high-throughput screening (MSHTS) assays $[27,28]$. EC $_{50}$ values were measured from inhibition curves, in which the percent SDs of fluorescence intensities were plotted against the concentration of each compound (Figure 3). Here, $30 \mathrm{nM}$ quantum dot amyloid beta (QDA $\beta$ ) and $30 \mu \mathrm{M}$ of $\mathrm{A} \beta$ were incubated with different concentrations to evaluate the $\mathrm{EC}_{50}$ of all derivatives. DCA and its derivative compound 4 showed relatively potent inhibition activities, with $\mathrm{EC}_{50}$ values of 57 and $74 \mu \mathrm{M}$, respectively, similar to the $\mathrm{EC}_{50}$ of rosmarinic acid $(60 \mu \mathrm{M})$ [27]. The inhibitory activities of hongoquercin A (7) and ginkgolic acids $(\mathbf{8}, \mathbf{9})$ for $\mathrm{A} \beta$ aggregation were lower, with $\mathrm{EC}_{50}$ values of 150-300 $\mu \mathrm{M}$. The inhibitory activities of the other cyclized DCAs and malabaricones were lower (Figure S2). These results indicate that DCA, a terpenoid containing a benzopyran moiety, is a candidate inhibitor of $A \beta$ aggregation, and that the carboxylic acid group on aromatics and hydrophobic long alkyl chains may be required for this activity. 
<smiles>CCCCCC/C=C/CCCCCCCc1cccc(O)c1C(=O)O</smiles>

(8)

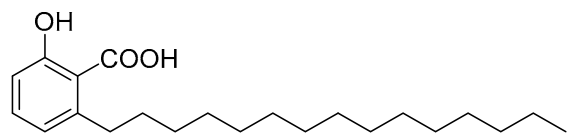

(9)

Figure 2. ginkgolic acids $(\mathbf{8}, \mathbf{9})$.

A

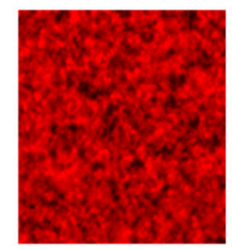

0.1

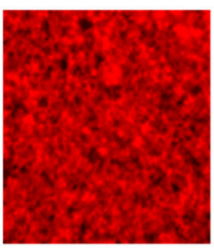

1

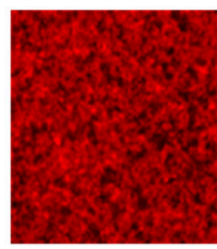

10

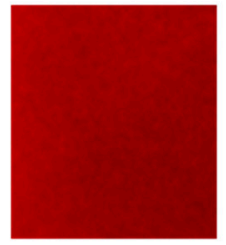

100

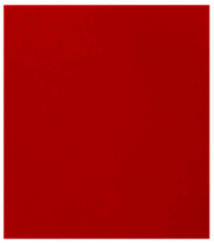

1000

$(\mu \mathrm{g} / \mathrm{ml})$

B
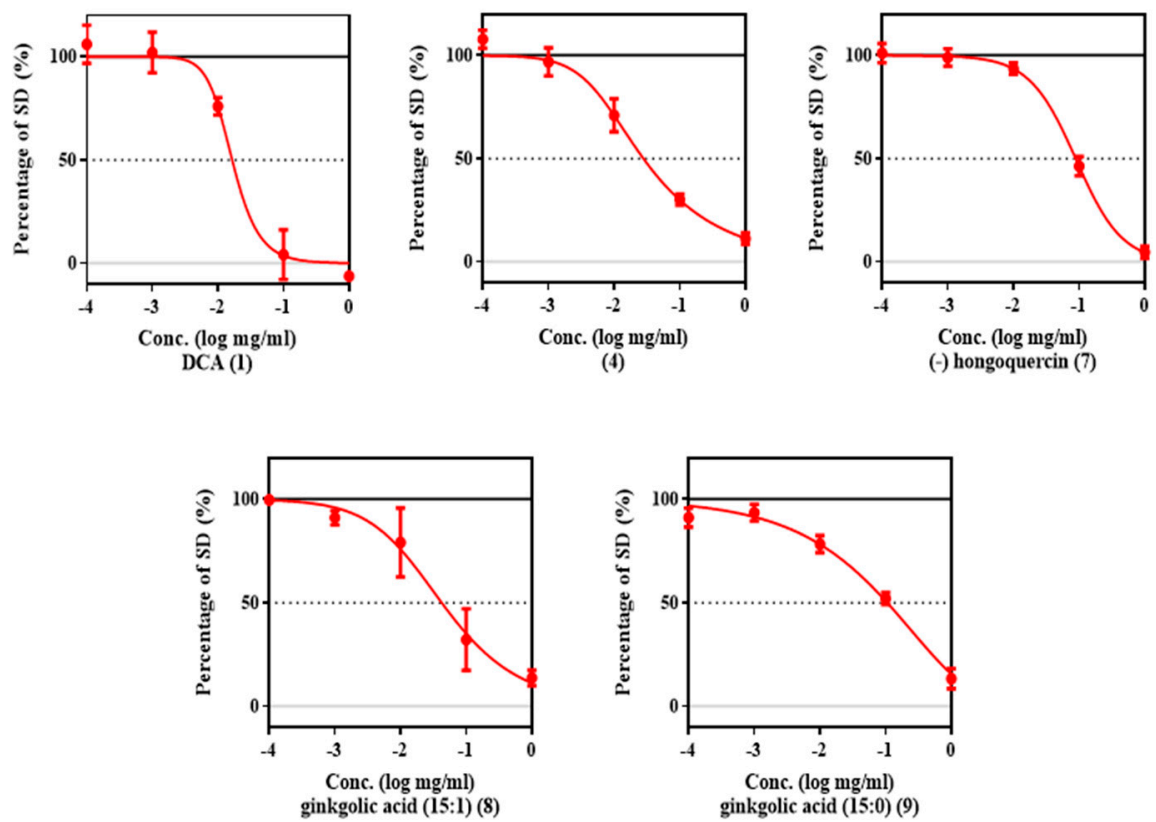

Figure 3. (A) Inhibition of $A \beta_{42}$ aggregation by DCA, its derivatives, and natural sphingomyelin synthase inhibitors, as shown by incubation of $30 \mathrm{nM} Q D A \beta$ and $30 \mu \mathrm{M} \mathrm{A} \beta$ with various concentrations of these compounds. (B) Estimation of $\mathrm{EC}_{50}$ values from inhibition curves, in which the percent SDs of fluorescence intensities were plotted against the concentrations of these compounds.

\subsection{DCA and Compound (4) Inhibit Both SMS and A $\beta$ Aggregation}

These studies' findings indicated that DCA and its derivative compound 4 could be new dual inhibitors of SMS activity and $A \beta_{42}$ aggregation. DCA was recently reported to inhibit the aggregation of $A \beta_{40}$ [29], similar to our findings that DCA inhibits the aggregation of $A \beta_{42}$. Furthermore, SAR studies of the ability of a terpenoid containing a benzopyran moiety to inhibit both SMS activity and $\mathrm{A} \beta_{42}$ aggregation suggested that benzoic acid and hydrophobic long alkyl chains are essential for both activities (Table 1). 
Table 1. Inhibitory activities of DCA, its derivatives, and natural sphingomyelin synthase towards SMS activity and $A \beta_{42}$ aggregation.

\begin{tabular}{cccc}
\hline Compounds & $\begin{array}{c}\text { SMS Assay (SMS1) } \\
\left(\mathrm{IC}_{\mathbf{5 0}} \text { in } \boldsymbol{\mu M}\right)\end{array}$ & $\begin{array}{c}\text { SMS Assay (SMS2) } \\
\left(\mathrm{IC}_{\mathbf{5 0}} \text { in } \boldsymbol{\mu M}\right)\end{array}$ & $\begin{array}{c}\text { MHSTS Assay } \\
\left.\mathbf{( E C}_{\mathbf{5 0}} \text { in } \boldsymbol{\mu M}\right)\end{array}$ \\
\hline $\mathbf{1}$ & 7 & 4 & 57 \\
$\mathbf{4}$ & 17 & 10 & 74 \\
$\mathbf{7}$ & 4 & 5 & 238 \\
$\mathbf{8}$ & 1.5 & 1.5 & 149 \\
$\mathbf{9}$ & 2 & 2 & 296 \\
\hline
\end{tabular}

Natural products are a source of potential pharmacological agents with an abundance of novel chemical entities with various biological activities. The goal of our study is to identify potent SMS inhibitors from a natural source. In this study, we found that DCA (1), which is isolated from a Rhododendron dauricum, is a potent SMS inhibitor. Leaves of Rhododendron dauricum are reported as anti-HIV, used for the treatment of many diseases, and are also involved in cell proliferation, as well as being one of the well-known, practically used Chinese traditional medicines. DCA (1) itself possesses several biological activities, popularly anti-HIV and antibacterial, but its molecular mechanisms have not yet been examined. To completely understand the pharmalogical behavior of DCA (1) with sphingomyelin synthase enzyme, a series of DCA derivatives 2-6 and (-) hongoquercin A (7) were synthesized to evaluate functional group participation in the enzyme inhibiton. Structures of isolated and all synthesized compounds were analyzed using various spectroscopic methods such as UV, IR, ESI-MS, and optical rotation for synthesized compounds. Compounds with SMS inhibition properties against cell-based assays and the fluorescent substrate C6-NBD (4-nitrobenzo-2-oxa-1,3-diazole)-Cer share a carboxylic acid moiety which is also related to anti-aggregative properties against amyloid beta protein. MSHTS assays were used to evaluate amyloid beta aggregation activity using DCA and their derivatives. DCA (1) and compound 4 with the presence of a carboxylic acid group tend to inhibit both SMS and $A \beta$ aggregation inhibition. Our work, to the best of our knowledge, is the first report on daurichromenic acid and derivatives of DCA and compound 4 as a dual inhibitor for sphingomyelin synthase and amyloid beta aggregation.

\section{Materials and Methods}

NMR spectra were recorded on a Varian Inova instrument $(500 \mathrm{MHz})$ at $25^{\circ} \mathrm{C}$ in $\mathrm{CDCl}_{3}$, and $\mathrm{CD}_{3} \mathrm{OD}$ using tetramethyl silane (TMS) as an internal standard. The NMR solvents $\mathrm{CDCl}_{3}$ and $\mathrm{CD}_{3} \mathrm{OD}$ were purchased from Cambridge Isotope Laboratories (Tewksbury, MA, USA). Chemical shifts $(\delta)$ were reported in parts per million (ppm) and coupling constant values $(J)$ in $\mathrm{Hertz}(\mathrm{Hz})$ relative to $\mathrm{CDCl}_{3}$ $(1 \mathrm{H}, \delta 7.26 ; 13 \mathrm{C}, \delta 77.00)$ or $\mathrm{CD}_{3} \mathrm{OD}(1 \mathrm{H}, \delta 3.4,4.8 ; 13 \mathrm{C}, \delta 49.3)$ and tetramethyl silane. The following abbreviations were used for signal multiplicities: $\mathrm{s}=$ singlet; $\mathrm{d}=$ doublet; $\mathrm{t}=$ triplet; $\mathrm{q}=$ quartet, and $\mathrm{m}$ $=$ multiplet. All other solvents were of reagent grade and were purchased from Kanto Chemical (Tokyo, Japan). ESI-MS spectra were recorded on a JEOL JMS-T100LP spectrometer (JEOL, Akishima, Japan). Melting points were measured on a Micro Melting Point Apparatus (Yanaco Co., Ltd., Kumiyama, Japan). Analytical thin-layer chromatography (TLC) was performed on $0.2 \mathrm{~mm}$ silica gel plates (Merck 60 F-254), (Darmstadt, Germany), developed with $\mathrm{CHCl}_{3}: \mathrm{MeOH}: \mathrm{H}_{2} \mathrm{O}$ (65:35:10, lower phase) and sprayed with a mixture of $5 \%$ ammonium molybdate and $1 \%$ cerium (IV) sulphate in $3.6 \mathrm{~N} \mathrm{H}_{2} \mathrm{SO}_{4}$ (Hanessian stain solution), or viewed with a handheld UV lamp (UVGL-58) at $254 \mathrm{~nm}$.

\subsection{Extraction and Isolation of Active Compounds from Rhododendron dauricum}

Rhododendron dauricum leaves were collected in Hokkaido, Japan, dried, and ground into powder. The dried powder, weighing $81 \mathrm{~g}$, was extracted three times with $400 \mathrm{~mL}$ methanol for $24 \mathrm{~h}$ each at room temperature. The methanol extracts were combined and concentrated under reduced pressure, yielding a black residue weighing $24.2 \mathrm{~g}$. The residue was dissolved in $20 \% \mathrm{MeOH}$ in water $(500 \mathrm{~mL})$ 
and partitioned three times with $200 \mathrm{~mL}$ hexane, three times with $200 \mathrm{~mL} \mathrm{Et}_{2} \mathrm{O}$, and three times with $200 \mathrm{~mL}$ EtOAc. The solvents were evaporated, and SMS activities were assessed in the hexane, $\mathrm{Et}_{2} \mathrm{O}$, EtOAc, and water residues. The hexane fraction was more active than the $\mathrm{Et}_{2} \mathrm{O}$ fraction, whereas the EtOAc and water fractions were inactive. The active hexane fraction, weighing $3.8 \mathrm{~g}$, was further fractionated by column chromatography on a spherical silica gel of diameter 40-50 $\mu \mathrm{m}$ (Kanto Silica Gel 60). The active component was identified as DCA, a finding confirmed by ${ }^{1} \mathrm{H}-\mathrm{NMR}$ and ESI-MS [20]. Yield: $1.53 \%(1.24 \mathrm{~g})$. Yellow oil, ${ }^{1} \mathrm{H}$ NMR $\left(\mathrm{CDCl}_{3}, 500 \mathrm{MHz}\right) \delta 11.71(1 \mathrm{H}, \mathrm{s}), 6.73(1 \mathrm{H}, \mathrm{d}, J=10 \mathrm{~Hz}), 6.23$ $(1 \mathrm{H}, \mathrm{s}), 5.48(1 \mathrm{H}, \mathrm{d}, J=10 \mathrm{~Hz}), 5.06-5.12(2 \mathrm{H}, \mathrm{m}), 2.52(3 \mathrm{H}, \mathrm{s}), 2.02-2.13(4 \mathrm{H}, \mathrm{m}), 1.95(2 \mathrm{H}, \mathrm{t}, 8.3 \mathrm{~Hz})$, $1.68-1.77(1 \mathrm{H}, \mathrm{m}), 1.67(3 \mathrm{H}, \mathrm{s}), 1.57-1.59(6 \mathrm{H}, 2 \mathrm{~s}), 1.40(3 \mathrm{H}, \mathrm{s})$. ESI-MS $(\mathrm{m} / \mathrm{z}): 353.46$ [M + $1-18]$.

\subsection{Synthesis of DCA Derivatives}

\subsubsection{Methyl Ester of DCA (2)}

A solution of TMS- $\mathrm{CH}_{2} \mathrm{~N}_{2}$ in hexane was added to a solution of DCA (compound 1) (100 mg, $0.270 \mathrm{mmol})$ in methanol $(5 \mathrm{~mL})$ and diethyl ether $(5 \mathrm{~mL})$ at $0{ }^{\circ} \mathrm{C}$ until the color of the solution became yellow. The reaction mixture was stirred at $0{ }^{\circ} \mathrm{C}$ for $0.5 \mathrm{~h}$ and at room temperature for $1 \mathrm{~h}$. The reaction was quenched with acetic acid and concentrated under vacuum to yield a residue, which was dissolved in hexane and purified by silica gel column chromatography using hexane/EtOAc (9.5:0.5) as an eluent, resulting in ester 2 [21] at a yield of $97 \%$. Colorless oil; ${ }^{1} \mathrm{H}$ NMR $\left(\mathrm{CDCl}_{3}, 500 \mathrm{MHz}\right) \delta 11.97(1 \mathrm{H}, \mathrm{s}), 6.72$ $(1 \mathrm{H}, \mathrm{d}, J=10 \mathrm{~Hz}), 6.18(1 \mathrm{H}, \mathrm{s}), 5.47(1 \mathrm{H}, \mathrm{d}, J=10.2 \mathrm{~Hz}), 5.05-5.11(2 \mathrm{H}, \mathrm{m}), 3.91(3 \mathrm{H}, \mathrm{s}), 2.45(3 \mathrm{H}, \mathrm{s})$, $1.93-2.10(6 \mathrm{H}, \mathrm{m}) 2.97-3.00,1.57-1.76(2 \mathrm{H}, \mathrm{m}), 1.66(3 \mathrm{H}, \mathrm{s}), 1.56-1.58(6 \mathrm{H}, 2 \mathrm{~s}), 1.39(3 \mathrm{H}, \mathrm{s})$. ESIMS $(\mathrm{m} / \mathrm{z})$ : $385.50[\mathrm{M}+\mathrm{H}]^{+}$.

3.2.2. Methyl(S,E)-2-(4,8-dimethylnona-3,7-dien-1-yl)-5-methoxy-2,7-dimethyl-2H-chromene-6 carboxylate (3)

$\mathrm{CH}_{3} \mathrm{I}(55 \mathrm{mg}, 0.400 \mathrm{mmol})$ was added to a solution of DCA (1) $(59.0 \mathrm{mg}, 0.160 \mathrm{mmol})$ in DMF ( $\left.3 \mathrm{~mL}\right)$ at room temperature, and the reaction mixture was stirred at $90{ }^{\circ} \mathrm{C}$ overnight. The reaction mixture was brought to room temperature and extracted with EtOAc. The organic layer was concentrated, and the residue was dissolved in hexane and purified by silica gel column chromatography using hexane/EtOAc (9:1) as an eluent, resulting in $59.0 \mathrm{mg}$ of compound 3 (yield 94\%). Colorless oil; ${ }^{1} \mathrm{H}$ NMR $\left(\mathrm{CDCl}_{3}, 500 \mathrm{MHz}\right) \delta 6.55(1 \mathrm{H}, \mathrm{d}, J=10 \mathrm{~Hz}), 6.42(1 \mathrm{H}, \mathrm{s}), 5.56(1 \mathrm{H}, \mathrm{d}, J=10 \mathrm{~Hz}), 5.06-5.11(2 \mathrm{H}, \mathrm{m}), 3.89$ $(3 \mathrm{H}, \mathrm{s}), 3.78(3 \mathrm{H}, \mathrm{s}), 2.24(3 \mathrm{H}, \mathrm{s}), 1.94-2.05(6 \mathrm{H}, \mathrm{m}), 1.56-1.58(2 \mathrm{H}, \mathrm{m}), 1.67(3 \mathrm{H}, \mathrm{s}), 1.56-1.58(6 \mathrm{H}, 2 \mathrm{~s})$, $1.38(3 \mathrm{H}, \mathrm{s})$. ESIMS $(\mathrm{m} / \mathrm{z}): 399.81[\mathrm{M}+\mathrm{H}]^{+}$.

3.2.3. (S,E)-2-(4,8-Dimethylnona-3,7-dien-1-yl)-5-methoxy-2,7-dimethyl-2H-chromene-6-carboxylic acid (4)

A solution of $6 \mathrm{M} \mathrm{NaOH}(5 \mathrm{~mL})$ was added to a solution of compound $3(50.0 \mathrm{mg}, 0.130 \mathrm{mmol})$ in methanol $(2 \mathrm{~mL})$ and THF $(2 \mathrm{~mL})$ at room temperature, and the reaction mixture was stirred at $100{ }^{\circ} \mathrm{C}$ for $2 \mathrm{~h}$. The reaction mixture was brought to room temperature, the solvent was evaporated, and the residue was neutralized with $2 \mathrm{~N} \mathrm{HCl}$ and extracted with EtOAc. The organic layer was concentrated, and the residue was dissolved in hexane and purified by silica gel column chromatography using hexane/EtOAc (9.5:0.5) as an eluent, resulting in $59.0 \mathrm{mg}$ of compound 4 (yield 83\%). Colorless oil; 1H NMR $\left(\mathrm{CDCl}_{3}, 500 \mathrm{MHz}\right) \delta 10.50(1 \mathrm{H}, \mathrm{s}), 6.55(1 \mathrm{H}, \mathrm{d}, J=10.2 \mathrm{~Hz}), 6.53(1 \mathrm{H}, \mathrm{s}), 5.63(1 \mathrm{H}, \mathrm{d}, J=9.2 \mathrm{~Hz})$, 5.06-5.11(2H, m), $3.87(3 \mathrm{H}, \mathrm{s}), 2.50(3 \mathrm{H}, \mathrm{s}), 1.94-2.15(6 \mathrm{H}, \mathrm{m}) 2.97-3.00,1.65-1.80(2 \mathrm{H}, \mathrm{m}), 1.67(3 \mathrm{H}, \mathrm{s})$, $1.56-1.58(6 \mathrm{H}, 2 \mathrm{~s}), 1.41(3 \mathrm{H}, \mathrm{s})$. ESIMS $(m / z): 385.32[\mathrm{M}+\mathrm{H}]^{+}$.

\subsection{4. (-)-(5R,8S,10R)-9,15-Didehydro hongoquercin A methyl ester (5)}

Ferric chloride $(81 \mathrm{mg}, 499 \mu \mathrm{mol})$ was added to a solution of $2(194 \mathrm{mg}, 505 \mu \mathrm{mol})$ in toluene $(10 \mathrm{~mL})$ at room temperature and the solution stirred for $8 \mathrm{~h}$ until the disappearance of the starting material. The toluene was evaporated, and the residue dissolved in $10 \mathrm{~mL}$ of water, followed by 
extraction with ethyl acetate. The combined organic layer was dried over $\mathrm{Na}_{2} \mathrm{SO}_{4}$, and the residue was dissolved in hexane and purified by silica gel column chromatography using hexane/EtOAc (9.5:0.5) as an eluent, resulting in compound 5 as a white solid (yield, 46\%). ${ }^{1} \mathrm{H} \mathrm{NMR}\left(\mathrm{CDCl}_{3}, 500 \mathrm{MHz}\right) \delta 11.99$ $(1 \mathrm{H}, \mathrm{s}), 6.50(1 \mathrm{H}, \mathrm{s}), 6.19(1 \mathrm{H}, \mathrm{s}), 3.91(3 \mathrm{H}, \mathrm{s}), 2.45(3 \mathrm{H}, \mathrm{s}), 2.20(1 \mathrm{H}, \mathrm{ddd}, J=3.5,3.5,13.0 \mathrm{~Hz}), 2.05(1 \mathrm{H}, \mathrm{d}$, $J=12.5 \mathrm{~Hz}), 1.90(1 \mathrm{H}, \mathrm{ddd}, J=4.5,13.0,13.0 \mathrm{~Hz}), 1.80(1 \mathrm{H}, \mathrm{d}, J=13.5 \mathrm{~Hz}), 1.65-1.70(1 \mathrm{H}, \mathrm{m}), 1.58-1.62$ $(1 \mathrm{H}, \mathrm{m}), 1.44(3 \mathrm{H}, \mathrm{s}), 1.41-1.52(3 \mathrm{H}, \mathrm{m}), 1.17(3 \mathrm{H}, \mathrm{s}), 1.09-1.20(2 \mathrm{H}, \mathrm{m}), 0.92(3 \mathrm{H}, \mathrm{s}), 0.86(3 \mathrm{H}, \mathrm{s})$; ESIMS $(m / z): 385.10[\mathrm{M}+\mathrm{H}]^{+}$.

\subsection{5. (-)-(5R,8S,10R)-9,15-Didehydro hongoquercin A (6)}

A solution of $6 \mathrm{M} \mathrm{NaOH}(1.5 \mathrm{~mL})$ was added to a solution of compound $5(27.0 \mathrm{mg}, 69.9 \mu \mathrm{mol})$ in methanol $(1 \mathrm{~mL})$ and THF $(2 \mathrm{~mL})$. The mixture was refluxed for $2 \mathrm{~h}$, acidified with $2 \% \mathrm{HCl}$, and extracted with $\mathrm{CH}_{2} \mathrm{Cl}_{2}$. The combined organic layer was washed with saline solution, dried over $\mathrm{Na}_{2} \mathrm{SO}_{4}$, and concentrated. The crude residue was purified by silica gel column chromatography using hexane/EtOAc (4:1) as an eluent, resulting in compound 6 [20] as a white solid (yield 84\%). ${ }^{1} \mathrm{H} \mathrm{NMR}$ $\left(\mathrm{CDCl}_{3}, 500 \mathrm{MHz}\right) \delta 11.69(1 \mathrm{H}, \mathrm{s}), 6.50(1 \mathrm{H}, \mathrm{s}), 6.24(1 \mathrm{H}, \mathrm{s}), 2.53(3 \mathrm{H}, \mathrm{s}), 2.20(1 \mathrm{H}, \mathrm{ddd}, J=3.5,3.5$, $13.0 \mathrm{~Hz}), 2.05(1 \mathrm{H}, \mathrm{d}, J=12.5 \mathrm{~Hz}), 1.90(1 \mathrm{H}, \mathrm{ddd}, J=4.5,13.0,13.0 \mathrm{~Hz}), 1.79(1 \mathrm{H}, \mathrm{d}, J=13.5 \mathrm{~Hz})$, 1.64-1.70 (1H, m), 1.56-1.61 (1H, m), $1.42(3 \mathrm{H}, \mathrm{s}), 1.37-1.51(3 \mathrm{H}, \mathrm{m}), 1.16(3 \mathrm{H}, \mathrm{s}), 1.08-1.20(2 \mathrm{H}, \mathrm{m})$, $0.91(3 \mathrm{H}, \mathrm{s}), 0.86(3 \mathrm{H}, \mathrm{s})$; ESI-MS $(\mathrm{m} / \mathrm{z}): 393.30[\mathrm{M}+\mathrm{Na}]^{+}$.

\subsection{6. (-) Hongoquercin A (7)}

A solution of $10 \% \mathrm{Pd} / \mathrm{C}(0.028 \mathrm{mmol})$ was added to a solution of $6(0.140 \mathrm{mmol})$ in EtOAc $(10 \mathrm{~mL})$ while stirring, and the reaction mixture was further stirred overnight at $40{ }^{\circ} \mathrm{C}$ under a $\mathrm{H}_{2}$ atmosphere. The solid was filtered off and the filtrate was concentrated under a vacuum. The residue was redissolved in hexane and purified by silica gel column chromatography using hexane/EtOAc (4:1) as an eluent, resulting in compound 7 (yield 74\%) as a white solid. Its structure was confirmed by ${ }^{1} \mathrm{H}$ - and ${ }^{13} \mathrm{C}-\mathrm{NMR}$ and ESI-MS and compared with previous results [18]. ${ }^{1} \mathrm{H}$ NMR $(500 \mathrm{MHz}$, $\left.\mathrm{CDCl}_{3}\right) \delta 11.78(1 \mathrm{H}, \mathrm{s}), 6.14(1 \mathrm{H}, \mathrm{s}), 2.63(1 \mathrm{H}, \mathrm{dd}, J=16.8 \mathrm{~Hz}), 2.44(3 \mathrm{H}, \mathrm{s}), 2.19-2.25(\mathrm{~m}, 1 \mathrm{H}), 2.01$ $(1 \mathrm{H}, \mathrm{dt}, 3.1,13.0 \mathrm{~Hz}), 1.69(2 \mathrm{H}, \mathrm{m}), 1.54-1.60(3 \mathrm{H}, \mathrm{m}), 1.48(1 \mathrm{H}, \mathrm{dd}, J=5.4,13.0 \mathrm{~Hz}), 1.38-1.43(1 \mathrm{H}, \mathrm{m})$, 1.28-1.35 (2H, m), $1.13(3 \mathrm{H}, \mathrm{s}), 0.96(1 \mathrm{H}, \mathrm{dd}, J=2.2,12.4 \mathrm{~Hz}), 0.90(1 \mathrm{H}, \mathrm{dd}, J=3.2,13.0 \mathrm{~Hz}), 0.85(3 \mathrm{H}, \mathrm{s})$, $0.83(3 \mathrm{H}, \mathrm{s}), 0.78(3 \mathrm{H}, \mathrm{s})[\alpha]_{D}^{23}=-109.1\left(\mathrm{c} 0.10, \mathrm{CHCl}_{3}\right) \operatorname{ESIMS}(m / z): 372.52[\mathrm{M}+\mathrm{H}]^{+}$.

\subsection{SMS Assay}

ZS/SMS1 and ZS/SMS2 cells (protein concentration $0.1 \mu \mathrm{g} / \mu \mathrm{L}$ ) were diluted in $20 \mathrm{mM}$ Tris-buffer ( $\mathrm{pH}$ 7.5) and sonicated. A $1 \mu \mathrm{L}$ aliquot of each compound at the desired concentration was added to $100 \mu \mathrm{L}$ aliquots of the cell lysates and the solutions were incubated at $37^{\circ} \mathrm{C}$ for $30 \mathrm{~min}$. A $1 \mu \mathrm{L}$ aliquot of C6-NBD-ceramide was added to each solution and the solutions were incubated for $3 \mathrm{~h}$ at $37^{\circ} \mathrm{C}$. The reactions were stopped by addition of $400 \mu \mathrm{L}$ of $\mathrm{MeOH} / \mathrm{CHCl}_{3}[1 / 2(v / v)]$, and the mixtures were shaken and centrifuged at $1500 \mathrm{rpm}$ for $5 \mathrm{~min}$. The formation of C6-NBD-sphingomyelin was quantified by HPLC determination of its peak area. Inhibitory activity was quantified by a reverse-phase HPLC assay using a JACSO HPLC system, equipped with a PU-2089 Plus and FP-2020 Plus set at $\lambda \mathrm{ex}=470 \mathrm{~nm}$ and $\lambda \mathrm{em}=530 \mathrm{~nm}$. A $50 \times 4.6$ YMC-Pack Diol-120-NP column $(5-\mu \mathrm{m}$ particle size) was used with the mobile phase (IPA/hexane/water) at a flow rate of $1.0 \mathrm{~mL} / \mathrm{min}$

\subsection{A $\beta$ Inhibition Aggregation Assay}

The aggregation inhibitory activities of plant extracts, fractions, DCA, DCA derivatives, and naturally occurring SMS inhibitors (compounds 8, 9, and 10) were measured using a modified MSHTS system [1,25]. Various concentrations of each were incubated with $30 \mathrm{nM}$ QD-labeled A $\beta_{40}$ (QDA $\beta$ ), and $30 \mu \mathrm{M} \mathrm{A} \beta_{42}$ in PBS containing 5\% EtOH and 3\% DMSO at $37{ }^{\circ} \mathrm{C}$ for $24 \mathrm{~h}$ in 1536 -well plates (782096, Greiner) (Kremsmünster, Austria). The center of each well as viewed with an inverted 
fluorescence microscope (TE2000, Nikon)) (Tokyo, Japan) equipped with a color CCD camera (DP72, Olympus) (Tokyo, Japan), and the central region of each well were measured with ImageJ software Ver 1.53b (NIH) to determine the standard deviations (SD) of fluorescence intensities of 40,000 pixels $(200 \times 200$ pixels: $320 \times 320 \mu \mathrm{m})[29,30]$. The SD values, which were approximately proportional to the amount of aggregates, were plotted against the concentrations of the putative inhibitors to generate inhibition curves, and the $\mathrm{EC}_{50}$ values were determined.

\section{Conclusions}

The present study showed that DCA, a terpenoid from the leaves of Rhododendron dauricum, is a natural inhibitor of sphingomyelin synthase. Several of its derivatives, including compounds 4, 6, and 7, also showed good inhibitory activity against SMS. In addition, DCA and compound 4 were found to inhibit $A \beta_{42}$ aggregation. These properties suggest that DCA is a suitable candidate for further development as a new drug or medicinal supplement to treat diseases of abnormal lipid metabolism and to prevent Alzheimer's disease.

Supplementary Materials: The following are available online. Figure S1: NMR spectra of daurichromenic acid and its derivatives, Figure S2: A $\beta$ aggregation inhibition activity of DCA and its derivatives.

Author Contributions: H.V.D., M.M.M.S., Y.S., Y.M., and K.U. contributed to performance, and analysis of the in vitro experiments, Y.S. and M.A. contributed plant samples. T.Y., M.K. and K.T. performed MSHTS assays. H.V.D., M.M.M.S., and K.M. wrote the manuscript. K.M. designed and supervised the study. All authors have read and agreed to the published version of the manuscript.

Funding: This work was supported by a grants-in-aid for scientific research KAKENHI (20H04756, 19 H02836 18K14350 and JP16H03288) from the MEXT of Japan, the MEXT Doctoral program for Data Related Innovation Expert Hokkaido University (D-DRIVEHU) and the photo-excitonix project at Hokkaido University. H.V.D. was supported by a scholarship grant from the International Graduate Program-Global Leaders in Life Science (IGP-GLLS) at Hokkaido University.

Conflicts of Interest: None of the authors has any conflicts of interest related to this article.

\section{References}

1. Cao, Y.; Chu, Q.; Ye, J. Chromatographic and electrophoretic methods for pharmaceutically active compounds in Rhododendron dauricum. J. Chromatogr. B Anal. Technol. Biomed. Life Sci. 2004, 812, 231-240. [CrossRef]

2. Taura, F.; Iijima, M.; Lee, J.B.; Hashimoto, T.; Asakawa, Y.; Kurosaki, F. Daurichromenic acid-producing oxidocyclase in the young leaves of Rhododendron dauricum. Nat. Prod. Commun. 2014, 9, 1329-1332. [CrossRef] [PubMed]

3. Saeki, H.; Hara, R.; Takahashi, H.; Iijima, M.; Munakata, R.; Kenmoku, H.; Fuku, K.; Sekihara, A.; Yasuno, Y.; Shinada, T.; et al. An aromatic farnesyltransferase functions in biosynthesis of the anti-HIV meroterpenoid daurichromenic acid. Plant Physiol. 2018, 178, 535-551. [CrossRef]

4. Iwata, N.; Wang, N.; Yao, X.; Kitanaka, S. Structures and histamine release inhibitory effects of prenylated orcinol derivatives from Rhododendron dauricum. J. Nat. Prod. 2004, 67, 1106-1109. [CrossRef] [PubMed]

5. Lee, K.H. Discovery and development of natural product-derived chemotherapeutic agents based on a medicinal chemistry approach. J. Nat. Prod. 2010, 73, 500-516. [CrossRef]

6. Taura, F.; Iijima, M.; Kurosaki, F. Daurichromenic acid and grifolic acid: Phytotoxic meroterpenoids that induce cell death in cell culture of their producer Rhododendron dauricum. Plant Signal. Behav. 2018, 13, e1422463. [CrossRef]

7. Tafesse, F.G.; Huitema, K.; Hermansson, M.; Van Der Poel, S.; Van Den Dikkenberg, J.; Uphoff, A.; Somerharju, P.; Holthuis, J.C.M. Both sphingomyelin synthases SMS1 and SMS2 are required for sphingomyelin homeostasis and growth in human HeLa cells. J. Biol. Chem. 2007, 282, 17537-17547. [CrossRef]

8. Mitsutake, S.; Zama, K.; Yokota, H.; Yoshida, T.; Tanaka, M.; Mitsui, M.; Ikawa, M.; Okabe, M.; Tanaka, Y.; Yamashita, T.; et al. Dynamic modification of sphingomyelin in lipid microdomains controls development of obesity, fatty liver, and type 2 diabetes. J. Biol. Chem. 2011, 286, 28544-28555. [CrossRef] 
9. Hanamatsu, H.; Ohnishi, S.; Sakai, S.; Yuyama, K.; Mitsutake, S.; Takeda, H.; Hashino, S.; Igarashi, Y. Altered levels of serum sphingomyelin and ceramide containing distinct acyl chains in young obese adults. Nutr. Diabetes 2014, 4, e141. [CrossRef]

10. Kim, Y.J.; Greimel, P.; Hirabayashi, Y. GPRC5B-mediated sphingomyelin synthase 2 phosphorylation plays a critical role in insulin resistance. iScience 2018, 8, 250-266. [CrossRef]

11. Yuyama, K.; Mitsutake, S.; Igarashi, Y. Pathological roles of ceramide and its metabolites in metabolic syndrome and Alzheimer's disease. Biochim. Biophys. Acta Mol. Cell Biol. Lipids 2014, 1841, 793-798. [CrossRef] [PubMed]

12. Ohnishi, T.; Hashizume, C.; Taniguchi, M.; Furumoto, H.; Han, J.; Gao, R.; Kinami, S.; Kosaka, T.; Okazaki, T. Sphingomyelin synthase 2 deficiency inhibits the induction of murine colitis-associated colon cancer. FASEB J. 2017, 9, 3816-3830. [CrossRef]

13. Swamy, M.M.M.; Murai, Y.; Ohno, Y.; Jojima, K.; Kihara, A.; Mitsutake, S.; Igarashi, Y.; Yu, J.; Yao, M.; Suga, Y.; et al. Structure-inspired design of a sphingolipid mimic sphingosine-1-phosphate receptor agonist from a naturally occurring sphingomyelin synthase inhibitor. Chem. Commun. 2018, 54, 12758-12761. [CrossRef] [PubMed]

14. Othman, M.A.; Yuyama, K.; Murai, Y.; Igarashi, Y.; Mikami, D.; Sivasothy, Y.; Awang, K.; Monde, K. Malabaricone $\mathrm{C}$ as natural sphingomyelin synthase inhibitor against diet-induced obesity and its lipid metabolism in mice. ACS Med. Chem. Lett. 2019, 10, 1154-1158. [CrossRef]

15. Jalencas, X.; Mestres, J. On the Origins of Drug Polypharmacology. Med. Chem. Commun. 2013, 4, 80-87. [CrossRef]

16. Paolini, G.V.; Shapland, R.H.B.; van Hoorn, W.P.; Mason, J.S.; Hopkins, A.L. Global mapping of pharmacological space. Nat. Biotechnol. 2006, 24, 805-815. [CrossRef]

17. Prati, F.; Uliassi, E.; Bolognesi, M.L. Two diseases, one approach: Multitarget drug discovery in Alzheimer's and neglected tropical diseases. MedChem Comm 2014, 5, 853-861. [CrossRef]

18. Ren, B.; Liu, Y.; Zhang, Y.; Cai, Y.; Gong, X.; Chang, Y.; Xu, L.; Zheng, J. Genistein: A dual inhibitor of both amyloid $\beta$ and human islet amylin peptides. ACS Chem. Neurosci. 2018, 9, 1215-1224. [CrossRef]

19. Ono, K.; Yamada, M. Antioxidant compounds have potent anti-fibrillogenic and fibril-destabilizing effects for alpha-synuclein fibrils in vitro. J. Neurochem. 2006, 97, 105-115. [CrossRef]

20. Zhou, X.; Wang, Y.; Lee, W.Y.W.; Or, P.M.Y.; Wan, D.C.C.; Kwan, Y.W.; Yeung, J.H.K. Miltirone is a dual inhibitor of P-glycoprotein and cell growth in Doxorubicin-resistant HepG2 cells. J. Nat. Prod. 2015, 78, 2266-2275. [CrossRef]

21. Janefjord, E.; Mååg, J.L.V.; Harvey, B.S.; Smid, S.D. Cannabinoid effects on $\beta$ amyloid fibril and aggregate formation, neuronal and microglial-activated neurotoxicity in vitro. Cell. Mol. Neurobiol. 2014, 34, 31-42. [CrossRef] [PubMed]

22. Mándi, A.; Swamy, M.M.M.; Taniguchi, T.; Anetai, M.; Monde, K. Reducing molecular flexibility by cyclization for elucidation of absolute configuration by CD calculations: Daurichromenic acid. Chirality 2016, 28, 453-459. [CrossRef] [PubMed]

23. Roll, D.M.; Manning, J.K.; Carter, G.T. Hongoquercins A and B, new sesquiterpenoid antibiotics: Isolation, structure elucidation, and antibacterial activity. J. Antibiot. 1998, 51, 635-639. [CrossRef] [PubMed]

24. Abbanat, D.A.; Singh, M.P.; Greenstein, M. Hongoquercins, new antibacterial agents from the fungus LL-23G227: Fermentation and biological activity. J. Antibiot. 1998, 51, 708-714. [CrossRef] [PubMed]

25. Tsujimori, H.; Bando, M.; Mori, K. Synthesis and absolute configuration of hongoquercin a, an antibacterial sesquiterpene-substituted orsellinic acid isolated as a fungal metabolite. Eur. J. Org. Chem. 2000, 2020,297-302. [CrossRef]

26. Giorgetti, S.; Greco, C.; Tortora, P.; Aprile, F.A. Targeting amyloid aggregation: An overview of strategies and mechanisms. Int. J. Mol. Sci. 2018, 19, 2677. [CrossRef]

27. Ishigaki, Y.; Tanaka, H.; Akama, H.; Ogara, T.; Uwai, K. A microliter-scale high-throughput screening system with quantum-dot nanoprobes for amyloid- $\beta$ aggregation inhibitors. PLoS ONE 2013, 8, e72992. [CrossRef]

28. Tokuraku, K.; Ikezu, T. Imaging of amyloid $\beta$ aggregation using a novel quantum dot nanoprobe and its advanced applications. In Bio-Nanoimaging: Protein Misfolding and Aggregation; Academic Press: Cambridge, MA, USA, 2014; pp. 121-131. 
29. Akiba, M.; Kinoshita, K.; Kino, Y.; Sato, J.I.; Koyama, K. Isolation of three new meroterpenoids and seven known compounds from Albatrellus yasudae and their A $\beta$-aggregation inhibitory activity. Bioorg. Med. Chem. Lett. 2020, 30, 126808. [CrossRef]

30. Sasaki, R.; Tainaka, R.; Ando, Y.; Hashi, Y.; Deepak, H.V.; Suga, Y.; Murai, Y.; Anetai, M.; Monde, K.; Ohta, K.; et al. An automated microliter-scale high-throughput screening system (MSHTS) for real-time monitoring of protein aggregation using quantum-dot nanoprobes. Sci. Rep. 2019, 9, 2587. [CrossRef]

Sample Availability: Samples of the compounds are not available from the authors.

(C) 2020 by the authors. Licensee MDPI, Basel, Switzerland. This article is an open access article distributed under the terms and conditions of the Creative Commons Attribution (CC BY) license (http://creativecommons.org/licenses/by/4.0/). 